This PDF is a selection from a published volume from the National Bureau of Economic Research

Volume Title: International Financial Issues in the Pacific Rim: Global Imbalances, Financial Liberalization, and Exchange Rate Policy (NBER-EASE Volume 17)

Volume Author/Editor: Takatoshi Ito and Andrew K. Rose, editors

Volume Publisher: The University of Chicago Press

Volume ISBN: 0-226-38682-1

Volume URL: http://www.nber.org/books/ito_08-1

Conference Dates: June 22-24, 2006

Publication Date: July 2008

Chapter Title: Are Currency Appreciations Contractionary in China?

Chapter Author: Jianhuai Shi

Chapter URL: http://www.nber.org/chapters/c6980

Chapter pages in book: (71 - 105) 


\title{
Are Currency Appreciations Contractionary in China?
}

\author{
Jianhuai Shi
}

\subsection{Introduction}

In recent years, the renminbi (RMB) exchange rate and China's exchange rate policy have received the extensive concern of the international community. Has RMB been undervalued? If so, by how much it is undervalued? Should RMB be revaluated or appreciated? These questions have all caused a hot debate at home and abroad. Though there is no unanimous conclusion on how much RMB is undervalued, it is the more unanimous view of researchers that RMB is undervalued. For example, Goldstein (2004) estimates that RMB has been undervalued by 15-30 percent in 2003 according to a simple fundamental equilibrium exchange rate (FEER) model. Frankel (2004) uses a modified purchasing power parity method to estimate that RMB was undervalued by 35 percent in 2000 , and judges that it is undervalued at least that much at present. Shi and Yu (2005) use a behavior equilibrium exchange rate (BEER) model to draw that RMB was undervalued by about 12 percent on average during 2002-2004, and Coudert and Couharde (2005) use a FEER model to estimate that the RMB exchange rate was undervalued by 23 percent in 2003 .

No matter if currency is being undervalued or overvalued, exchange rate

Jianhuai Shi is a professor at the China Center for Economic Research (CCER) at Peking University.

This is a revision of a paper presented at the 17th Annual East Asian Seminar on Economics on International Financial Issues around the Pacific-Rim, Hawaii, June 22-24, 2006, organized by the National Bureau of Economic Research. I thank Ashvin Ahuja, Dante Canlas, Michael Dooley, Peter Garber, Takatoshi Ito, and Andrew Rose for insightful comments, and Guoqing Song for help in obtaining data used in this research. The views expressed herein are those of the author and do not necessarily reflect the views of the National Bureau of Economic Research. 
misalignment certainly results in a distortion of the economy that exerts a negative impact on economic structure and macroeconomic performance of the economy. For example, in recent years, the Chinese economy has been in a state of obvious external and internal imbalance, ${ }^{1}$ which certainly has something to do with the undervaluation of RMB. According to the Swan Diagram, a classic framework for analyzing the macroeconomic policy of an open economy, allowing RMB to appreciate is a direct and effective method to resolve the imbalances of the Chinese economy (Shi 2006), but the Chinese government seems hesitant to allow RMB to appreciate ${ }^{2}$ and would rather adopt other measures such as adjusting export tax rebates, relaxing the controls on capital outflow, and adjusting the interest rate or deposit reserve ratio to deal with external and internal imbalances of the economy.

Why then, considering that there is obviously an undervaluation of RMB and that the Chinese economy suffers from external and internal imbalances, does the Chinese government still resist RMB appreciation? According to a traditional macroeconomics textbook model, currency appreciations are contractionary; at least in the short run, appreciations will raise the price of domestic goods relative to the price of foreign goods (namely the real exchange rate appreciation), cause exports to drop and consumers to substitute home produced goods with imported goods, and thus reduce the aggregate demand. ${ }^{3}$ So, the hesitation of the Chinese government is consistent with the view of traditional macroeconomic theory. Though the Chinese government has announced that China does not pursue too big a trade surplus, indicating that the Chinese policymakers would like to reduce the surplus through various means, the Chinese government certainly worries that RMB appreciations are contractionary, as traditional macroeconomic theory states, and thus would have a negative impact on China's economic growth and employment - even causing the Chinese economy to fall into a long time recession, as happened in Japan during the 1990s (as is often, but maybe not correctly, cited by those who argue against the RMB appreciation). This is the main reason the Chinese government is unwilling to allow RMB to appreciate. Considering that there is a high rate of unemployment caused by economic reform and economy transition into the market economy, maintaining the high rate of economic growth and sustaining employment are obviously the higher priorities of the Chinese government.

1. Specifically, external imbalance is evidenced by the large current account surplus and a large growth in foreign exchange reserves; the internal imbalance manifests itself in the overheating of the economy and the pressure of inflation.

2. Under China's new exchange rate regime, if the monetary authority reduces the intensity of exchange market intervention, or widens the band of RMB exchange rate floating, the market will promote RMB to appreciate progressively because of the steady expectation of RMB appreciation. In this paper, we do not distinguish appreciation from revaluation.

3. This is the expenditure-switching effect of exchange rate change. 
Must appreciations be contractionary and depreciations expansionary? For a long time, at least since Hirschman (1949), economists have realized that appreciations are not necessarily contractionary, nor are depreciations necessarily expansionary. Marked by Krugman and Taylor (1978), there appears a so-called contractionary devaluations literature. ${ }^{4} \mathrm{On}$ the demand side, the literature emphasizes the expenditure-changing effects of exchange rate change ignored by the traditional macroeconomic theory and provides a series of mechanisms and channels through which devaluation can cause outputs to drop. On the supply side, the literature demonstrates the contractionary devaluations effect mainly through the influence of devaluation on the cost of imported intermediate goods, the cost of wages and, firm's working capital. ${ }^{5}$ After the 1994 Mexico currency crisis and 1997-98 East Asian financial crisis, the contractionary devaluations literature obtained renewed attention of economists (Kamin and Rogers 2000), and has received new development. The new development emphasizes the importance of the balance sheet effects in explaining the economic recession caused by the devaluation in the financial crisis (Frankel 2005).

According to the contractionary devaluations literature, currency revaluations are likely to have an expansionary rather than a contractionary impact on the economy in developing countries. For instance, currency revaluation has real cash balance effect and real wealth effect: It lowers the domestic price level, therefore leading to real cash balance and real wealth increase, which tends to expand personal spending (Bruno 1979, Gylfason and Radetzki 1991). Currency revaluation also has an income reallocation effect (Diaz-Alejandro 1963, Cooper 1971, Krugman and Taylor 1978): it tends to transfer real income from groups with high marginal propensity to saving toward groups with low marginal propensity to saving, causing total domestic expenditure to expand. This is because revaluation raises the real wage through reducing the price level, causing the real income to shift from entrepreneur to the laborer, and the laborer has higher marginal propensity to consume than that of entrepreneur. This income reallocation effect may be remarkable in developing countries, because the laborers in developing countries usually have limited wealth and are subject to strong liquidity constraint, so their marginal propensities to consume are nearly equal to 1 . Moreover, in developing countries, new equipment investment usually includes a large amount of imported capital goods, and currency

4. This literature is mainly about the exchange rate policy of developing countries. Devaluations are usually included in stabilization programs of developing countries and the balance of payment problems in developing countries generally are devaluation pressure. Therefore, the contractionary devaluations literature mainly investigates the issue of devaluation. However, many channels of the contractionary devaluations are equally suitable to the issue of revaluation.

5. See Lizondo and Montiel (1989) for a survey of contractionary devaluations literature. Caves, Frankel, and Jones (2002) provide a simple introduction of ten kinds of contractionary devaluations effects. 
revaluation will lower domestic prices of those goods, which will help to expand investment expenditure and, therefore, total expenditure (Branson 1986, van Wijnbergen 1986). ${ }^{6}$ Finally, currency revaluation will lower the domestic prices of imported intermediate goods and raw materials (such as petroleum and minerals) which, in turn, will lower the production costs of all final goods (including nontradable goods) and the lowering of marginal costs relative to the prices of final goods will lead to increased output and employment (Bruno 1979, van Wijnbergen 1986). Therefore, even if the net effect of revaluation on aggregate demand is contractionary (the expenditure-switching effect is large enough to dominate the expenditurechanging effect), the existing supply side effect may still make the revaluation expansionary.

Regarding the empirical literature, the majority of research on the relationship between the real exchange rate and output in developing countries has demonstrated that real devaluations are contractionary while real appreciations were expansionary, suggesting that the channels the contractionary devaluations literature revealed are important in developing countries. For example, in an influential early research Edwards (1986) used a reduced form equation model to study a panel data set of 12 developing countries, and found that devaluations were contractionary in the shortterm, but turned out to be expansionary after one year, and were neutral in the long-term. Gylfason and Radetzki (1991) used a macroeconomic simulation method to find that for the 12 developing countries studied, devaluations were all contractionary in the short-term as well as in the mid-term. Kamin and Rogers (2000) used a vector autoregression model (VAR model) to study the relation between real exchange rate and output in Mexico, and found that real devaluations were contractionary while real appreciations were expansionary. Other recent researches, such as Hoffmaister and Vegh (1996) on Uruguay, Moreno (1999) on six East Asian countries, Akinlo and Odusola (2003) on Nicaragua, and Berument and Pasaogullari (2003) on Turkey, all support the contractionary devaluations hypothesis.

What is the relationship between RMB real exchange rate and China's output then? Are RMB appreciations contractionary as the textbook says, or expansionary as the contractionary devaluations hypothesis suggests? The purpose of this paper is to study the effects of RMB real exchange rate on China's output by using VAR models with a sample of 1991q1-2005q3. The rest of the paper is organized as follows: section 2 gives a brief historical review of China's exchange rate regime, the evaluations of the RMB real exchange rate, and China's output during the past decade, in order to provide a background for the issues to be discussed; section 3 describes the models to be employed and the data to be used, and discusses the time se-

6. Those are the expenditure-changing effects of exchange rate change. 
ries characteristics of the variables; section 4 takes an econometric analysis of the VAR models through impulse-response function graphs and variance decompositions of forecast errors; and finally, section 5 summarizes the conclusions drawn from this research.

\subsection{A Brief History of RMB Exchange Rate Evaluation and China's Output Fluctuation: 1991-2005}

In the early part of the 1990s, China implemented a double exchange rate system; an official fixed exchange rate coexisted with a market exchange rate formed in the swap foreign exchange market. By 1992, up to 80 percent of the foreign exchange transactions were conducted at the swap foreign exchange market and the market exchange rate essentially reflected the demand for and the supply of the foreign exchange. Because the swap market exchange rate was higher than official exchange rate, implying a subsidy to exporters, the double exchange rate system caused unfair competition and resource distortion, and was unfavorable for attracting foreign direct investments. ${ }^{7}$ Against these negative effects, the official exchange rate of RMB was increasing (devaluating) constantly, from 4.7 yuan per U.S. dollar in 1990, devalued to 5.4 yuan per dollar in 1992, until it reached 5.8 yuan per dollar by the end of 1993. On January 1, 1994, China reformed its double exchange rate system by unifying the two exchange rates and established a single and managed floating exchange rate system based on market supply and demand. Afterward, the nominal rate of RMB had gone through disconnected, small bouts of appreciation, and this course went on until 1997 and the financial crisis of East Asia.

When the external demand dropped and the currencies of China's principal trade partners devalued against the U.S. dollar by a wide margin (except Hong Kong), the market participators generally anticipated that RMB would follow those currencies and devaluate. In order to stabilize the regional exchange rates and prevent the currencies from competitive devaluation, the Chinese government announced against the market expectation that RMB would not be devalued. From then on, the RMB exchange rate was fixed at 8.28 yuan per U.S. dollar, and the so-called managed float became a de facto dollar peg. This system lasted until July of 2005. On July 21,2005 , China instituted a reform of its exchange rate regime by revaluating the RMB by 2.1 percent and terminating its peg to the U.S. dollar in favor of a managed float based on a basket of currencies. Under the new exchange rate regime, the daily fluctuation of RMB exchange rate is restricted within 0.3 percent on both sides, and the RMB exchange rate has

7. Under this kind of system, the foreign investment must be converted into RMB according to the official exchange rate first. When the foreign investors need foreign exchanges, however, they can only obtain them through the foreign exchange swap market, at the market exchange rate. 
not moved very much because of the market intervention conducted by the People's Bank of China (PBOC). Figure 3.1 portrays the track of RMB nominal exchange rate against the U.S. dollar during the past sixteen years.

In contrast with the relative stableness of the bilateral nominal rate of $\mathrm{RMB}$, the real effective exchange rate (hereafter referred to as the real exchange rate) of RMB presented a large fluctuation in the past periods of more than ten years. As can be seen from figure 3.2, the real exchange rate of RMB had gone through six different stages. (a) 1991q1-1993q2 - the real exchange rate of RMB experienced a large amount of depreciation, mainly because the nominal rate of RMB had presented a large devaluation; (b) 1993q3-1998q1 - the real exchange rate of RMB experienced a large amount of appreciation, mainly because of higher inflation in China during the period and a small appreciation of RMB nominal rate. After the financial crisis of East Asia, the appreciation of RMB real exchange rate was due to the sharp devaluations of the currencies of some China's trade partners. (c) 1998q2-1999q4 the real exchange rate of RMB experienced a certain degree of depreciation, mainly because there appeared to be a deflation in China; (d) 2000q1-2002q1 - a certain degree of appreciation of RMB real exchange rate appeared in this period, mainly the reflection of mild inflation in China and a deflation in the trade partners in this period. The real exchange rate of $\mathrm{RMB}$ of $2002 \mathrm{q} 1$ rebounded to the level of 1997q4. (e) 2002q2-2005q1 - the real exchange rate of RMB turned to the course of large depreciation, mainly influenced by the fact that the U.S. dollar depreciated largely against Euro, Japanese yen, and other key currencies, so RMB also depreciated largely against those currencies; (f) $2005 \mathrm{q} 2$ and $\mathrm{q} 3$ - subject to the influence of appreciation of the U.S. dollar

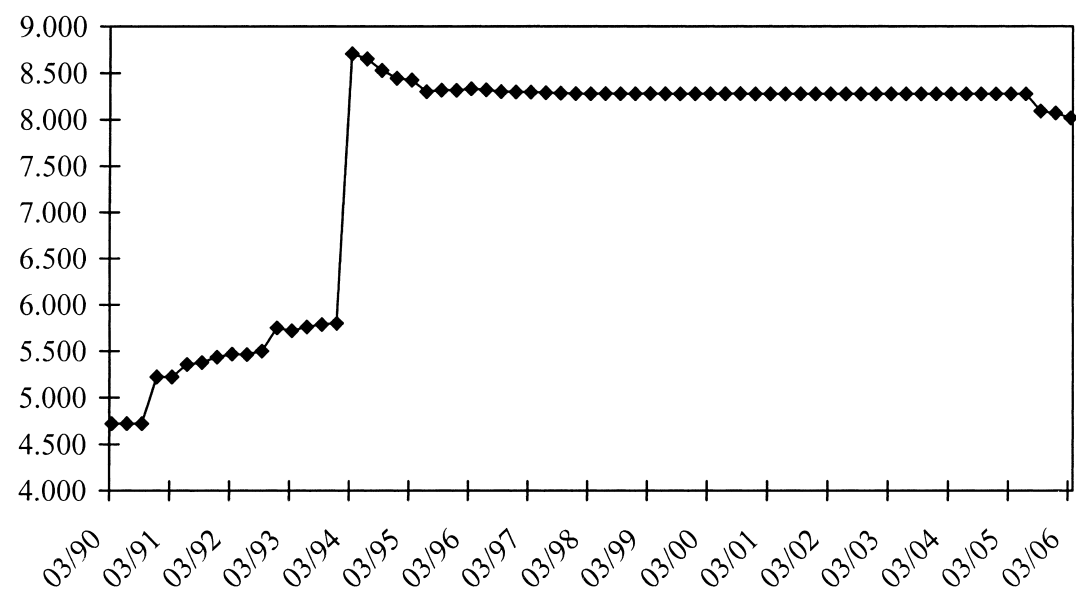

Fig. 3.1 RMB nominal exchange rate (yuan/U.S. dollar)

Source: IMF, International Financial Statistics 


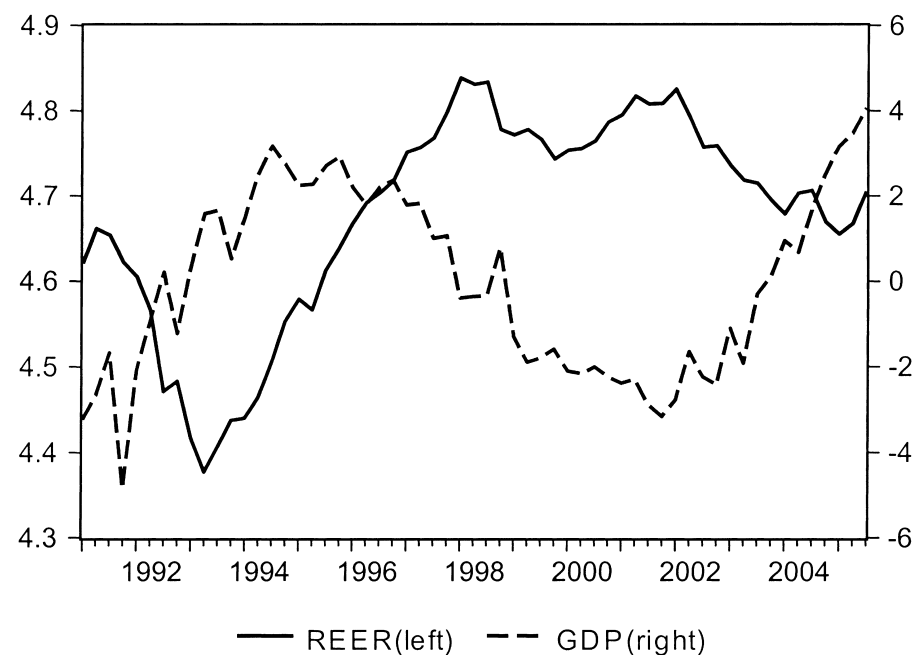

\section{Fig. 3.2 RMB real exchange rate and real GDP}

Note: REER stands for RMB real exchange rate index with a rise indicating an appreciation. GDP stands for detrended real gross domestic product. See section 3 for the definition and explanation of the variables.

against the Euro and Japanese yen, the RMB real exchange rate turned to an appreciation state again.

By investigating the detrended real output data of China, we can find that China's real output also experienced a large fluctuation over the past ten plus years. Concerning the correlation of the two variables, as figure 3.2 shows, during the whole sample period (1991q1-2005q3) the relationship between the RMB real exchange rate and China's cyclical output is not very clear, but since 2000q1 the two have presented an obvious negative correlation; namely, appreciations of the real exchange rate have been associated with falls of the cyclical outputs, while real depreciations have been followed by expansions of the cyclical output. The relation between RMB real exchange rate and China's output accords with the forecast of the traditional open economy macroeconomics- RMB appreciations are contractionary, while RMB depreciations are expansionary.

However, for the shown correlation between the RMB real rate and China's output in figure 3.2, two issues are still needed to be clarified: First, may the tight correlation between the RMB real rate and China's output be spurious? That is, is it just reflecting the response of both variables to the third external variable, and do the two variables have nothing to do with each other? For example, a change in government spending will influence the real exchange rate while influencing aggregate demand. Models in the Mundell-Fleming tradition predict that an increase in government spending raises the real interest rate and leads to an appreciation of the real ex- 
change rate. ${ }^{8}$ Second, if real exchange rate and output are really relevant, what then is the causality between them? In other words, does the change of the real exchange rate of RMB cause the change of output, or, conversely, does the change of the output cause the change of the real exchange rate of RMB? In order to draw the answers to the above-mentioned questions, we employ a preliminarily pairwise Granger causality test to examine the Granger causality between the RMB real rate and China's output. The Granger causality tests will indicate whether a set of lagged variables has explanatory power on the other variables. If the computed F-statistics are significant, we can claim in Granger's sense that one variable does cause the other variable.

Table 3.1 reports the results of the Granger causality test. The result of the test on the whole sample (1991q1-2005q3) shows that, with a 95 percent level of confidence, the sample data reject the null hypothesis, indicating that China's output Granger causes the RMB real rate, and the RMB real rate Granger causes the output as well. Because there seems a difference on the relationship between RMB real rate and China's output before and after $2000 \mathrm{q} 1$, we divide the whole sample into two subsamples (1991q1-1999q4 and 2000q1-2005q3) and conduct a Granger causality test on the two subsamples separately. The results turn out to be surprise. For the first subsample, the data reject the null hypothesis with a 99 percent level of confidence, suggesting the output Granger causes the real exchange rate, and the real exchange rate Granger causes the outputs as well. For the second subsample, upon which there seems to be a strong correlation between the output and real exchange rate, the date instead cannot reject the null hypothesis, showing the strange result that the output does not Granger cause the real exchange rate and the real exchange rate does not Granger cause the outputs either. That means no variable is helpful in explaining the movement of the other. One explanation to this strangelooking result may be that the number of observations in the second subsample is too small, resulting in a small F-Statistic. Another explanation may be that there are other variables influencing both RMB real rate and China's output at the same time that has limited the usefulness for the pairwise Granger causality test.

So, in order to investigate the relationship between the RMB real exchange rate and China's output more precisely, we employ VAR models to control the influence of variables that may have impacts on both RMB real exchange rate and China's output, in order to answer the above-mentioned questions. The estimated VAR models also let us study other interesting issues.

8. The sticky-price intertemporal models of the New Open Economy Macroeconomics predict a fall in the real interest rate in response to an increase in government spending (Obstfeld and Rogoff 1995), hence a depreciation of the real exchange rate. 
Table 3.1

Pairwise Granger causality tests

\begin{tabular}{|c|c|c|c|}
\hline Null Hypothesis & Obs. & F-Statistic & Probability \\
\hline \multicolumn{4}{|c|}{ Sample: 1991Q1-2005Q3 } \\
\hline GDP does not Granger Cause REER & 55 & 2.65 & 0.04 \\
\hline REER does not Granger Cause GDP & & 2.85 & 0.03 \\
\hline \multicolumn{4}{|c|}{ Subsample: 1991Q1-1999Q4 } \\
\hline GDP does not Granger Cause REER & 32 & 3.69 & 0.02 \\
\hline REER does not Granger Cause GDP & & 9.38 & 0.00 \\
\hline \multicolumn{4}{|c|}{ Subsample: $2000 Q 1-2005 Q 3$} \\
\hline GDP does not Granger Cause REER & 23 & 0.86 & 0.51 \\
\hline REER does not Granger Cause GDP & & 0.52 & 0.72 \\
\hline
\end{tabular}

\subsection{Model and Data}

\subsubsection{The Models}

We use the VAR model to study the relationship between the real exchange rate of RMB and China's output in order to find out whether the correlation indicated by figure 3.2 is spurious or not, and the direction of causality between the real exchange rate and output in China. Owing to the relatively small sample size, we can't include all interested variables within one VAR model, ${ }^{9}$ so we adopt the modeling strategy of Kamin and Rogers (2000) as follows: we estimate a basic model at first, and then expand the basic model by entering another external variable to the basic model each time. Following Kamin and Rogers (2000), the basic model includes China's gross domestic product (GDP), RMB real effective exchange rate (REER), China's inflation rate (INFL) and foreign gross domestic product (GDPF). Following the tradition of business cycle literature, we detrend the data of gross domestic product so as to focus upon the growth cycle. Therefore, GDP and GDPF represent the cyclical components of gross domestic product (or GDP gap) of China and foreign countries respectively. The reasons for selecting these four variables are as follows: GDPF is taken as a proxy of external shocks. This variable lets us examine the effect on Chinese economy of external shocks. GDP and REER are the variables we want to study. INFL is the intermediate variable in between the real exchange rate and output, proxying all possible channels link the real exchange rate to output. Being different from Kamin and Rogers (2000), we choose GDPF instead of the U.S. interest rate as the proxy of external factors. This is based on the following consideration: China still implements

9. Because a VAR model involves quite a lot of parameters to be estimated, introducing too many endogenous variables will cause serious loss in the degrees of freedom, thus affecting the statistic dependability of the results. 
the capital controls, therefore, the relation between the U.S. interest rate and China's interest rate should not be very close. On the other hand, after fulfilling the RMB convertible for current account transactions and formally joining the World Trade Organization, the openness of China's real economy is increasing constantly, and the ratio of foreign trade to GDP in China has reached a level of 70 percent at present. In this situation, the business cycles of trading partners have important influence on China through the channels of import and export.

The basic model is too parsimonious to allow us to investigate more comprehensive influences of the variables that influence both the real exchange rate and the output; it may not be very efficient to study the problem of spurious correlation. For example, it provides us with little sense of which channels link the real exchange rate to output. Therefore, we enter one endogenous variable into the basic model each time, and estimate other VAR models in addition. That lets us see whether our final results are robust or not, and at the same time lets us control the size of the VAR model within the appropriate level according to the sample. We enter government spending (GOV) and money supply (M2) into the basic model respectively to examine fiscal and monetary channels in the relationship between real exchange rate and output. In addition, we enter the U.S. interest rate (RUS) so as to investigate the international financial linkage of Chinese economy and examine the efficiency of capital controls in China. Therefore, besides the basic model that is indicated as model 1, we further estimate three more VAR models. The models can be expressed in the form of an unrestricted VAR model as follows:

$$
Y_{t}^{l}=\sum_{i=1}^{k_{l}} A_{t}^{l} Y_{t-i}^{l}+\varepsilon_{t}^{l}, \quad \varepsilon_{t}^{l} \sim \operatorname{IID}\left[o^{l}, \Omega^{l}\right], \quad l=\overline{1,4}
$$

where,

$$
\begin{aligned}
& Y_{t}^{1}=\left(G D P F_{t}, I N F L_{t}, \text { REER }_{t}, G D P_{t}\right)^{\prime}, \\
& Y_{t}^{2}=\left(G D P F_{t}, I N F L_{t}, G O V_{t}, R E E R_{t}, G D P_{t}\right)^{\prime}, \\
& Y_{t}^{3}=\left(G D P F_{t}, M 2_{t}, I N F L_{t}, R=E R_{t}, G D P_{t}\right)^{\prime}, \\
& Y_{t}^{4}=\left(R U S_{t}, G D P F_{t}, I N F L_{t}, R^{\prime} E E R_{t}, G D P_{t}\right)^{\prime},
\end{aligned}
$$

$k_{l}$ indicates the lags of $l$-th VAR model. $A_{t}^{l}$ is parameter matrix of $l$-th VAR model for $i=1,2, \ldots, k_{l}, \varepsilon_{t}^{l}$ is a random residual vector of $l$-th VAR model, $o^{l}$ is the zero mean vector of $\varepsilon_{t}^{l}$, and $\Omega^{l}$ is a covariance matrix of $\varepsilon_{t}^{l}$. Accordingly to AIC criterion and SC criterion, the different numbers of lags are tried for each VAR model, and the optimum lags turn out to be 4 for all four models.

We take the familiar two-stage approach to estimate the VAR models. At the first stage, the variables are regressed on lags of all the variables in the 
system, and at the second stage, the Cholesky decomposition technique used by Sims (1980) is employed to orthogonalize the residuals so as to identify the primitive structural system. The Cholesky decomposition imposes a recursive contemporaneous causal structure on the VAR models. The model variables are ordered in a particular sequence, and variables higher in the ordering are assumed to cause contemporaneous changes in variables lower in the ordering. Variables lower in the ordering are assumed to affect variables higher in the ordering only with a lag. Because of this, determining a reasonable order for endogenous variables is an important issue in employing a VAR model. We select the variable orders of our four models as above, and the rationale for the orderings are as follows.

GDPF is ordered first because GDPF captures the external shocks that may have significant contemporaneous effects on Chinese economic variables like INFL, REER, and GDP due to the openness of Chinese economy. On the other hand, the outputs of China's trade partners as a whole are unlikely affected contemporaneously by any Chinese economic variables. For REER, INFL, and GDP, we adopt an ordering a little bit different from that of Kamin and Rogers $(2000) ;{ }^{10}$ we order INFL prior to REER and GDP by assuming that inflation shocks have a contemporaneous effect on RMB real exchange rate (since RMB nominal exchange rate is stable due to high official intervention) and on aggregate demand. In contrast, we assume that price is sticky in the short run, so it responds to real exchange rate and aggregate demand shocks only with lags. REER is ordered prior to GDP, as we assume that real exchange rate shocks have a contemporaneous effect on aggregate demand through traditional channel or those indicated by the contractionary devaluations literature, while aggregate demand shocks do not affect contemporaneously the real exchange rate. In model 2, GOV is ordered after INFL by assuming that government spending shocks affect inflation only with a lag. In model 3, M2 is ordered prior to INFL under the assumption that as the monetary policy instrument in China, money supply reacts not to realized inflation but to expected inflation. In model 4, RUS is ordered prior to GDPF because U.S. interest rate shocks affect contemporaneously the world aggregate demand, but due to the relative closeness of U.S. economy, the U.S. interest rate is unlikely affected contemporaneously by world aggregate demand and any Chinese economic variables.

\subsubsection{The Data}

The data are quarterly; the sample interval is 1991q1-2005q3. 1991q1 is the earliest time for which the quarterly gross domestic product data are available in China. The gross domestic product data of 2005q4 is collected according to a new statistical method and without comparability with the 
data in the past, and therefore we exclude it from our sample. Except for inflation rate, variables are the real ones. U.S. real interest rate is obtained by subtracting the U.S. inflation rate from the nominal interest rate, and other real variables are drawn from the nominal ones divided by consumer price index. The base period is 1992 .

The foreign gross domestic product index, GDPF, is calculated according to the trade-weighted average of the gross domestic product indices of 14 principal trade partners of China. GDP and GDPF are detrended gross domestic products. In business cycle literature, the Hodrick-Prescott (H-P) filter is widely used to generate the cyclical components. It is well known, however, that the H-P filter has an end-of-sample problem, that is, at the end of the sample the estimates are particular unreliable. In addition, the filter depends on the choice of the "smoothness parameter" which makes the resulting cyclical component and its statistical properties highly sensitive to this choice. Those problems become serious when sample size is small. Because of the relatively small sample we have, we do not use the H$\mathrm{P}$ filter in this study. Instead, we use quadratic detrending to construct GDP and GDPF data, which is implemented by regressing the logarithm of quarterly real gross domestic product on a trend and its quadrate. The regression with a quadratic time trend has higher degree of fit than one with a linear time trend in our case.

REER (RMB real effective exchange rate index) is taken from the International Financial Statistics database of the International Monetary Fund (IMF), a rise in REER indicating an appreciation. China's inflation rate, INFL, is obtained by differencing the logarithm of consumer price index. GOV expresses the Chinese government spending. M2 is China's broad money supply. RUS indicates the U.S. real interest rate of three-month treasury bills. Except for INFL and RUS, variables are in the logarithm. GDP, GOV, INFL, and GDPF have been seasonally adjusted. Data of other countries or regions come from the International Financial Statistics database of IMF. The data of China's variables, except REER, come from the State Statistics Bureau, the People's Bank of China, China's Ministry of Finance, and General Customs of China. Taiwan GDP annual data come from the IMF World Economic Outlook Database 2006, which have been translated into quarterly data.

\subsubsection{The Time Series Characteristics of the Data}

Because many macroeconomic variables are not stationary, to avoid spurious regressions we need to test if the time series of relevant variables in our models are stationary or not. If the variables turn out to be nonstationary, we further need to know whether there exist long run steady relations among those endogenous variables or not. We take the unit root tests and cointegration tests for those purposes below. 
Unit root tests

\begin{tabular}{lccccc}
\hline & \multicolumn{2}{c}{ Level } & & \multicolumn{2}{c}{ First Difference } \\
\cline { 2 - 3 } \cline { 5 - 6 } & ADF Test & Phillips-Perron Test & & ADF Test & Phillips-Perron Test \\
\hline GDP & $-1.53^{*}$ & $-1.45^{*}$ & & $-1.88^{*}$ & $-9.26^{* *}$ \\
REER & $-1.27^{*}$ & $-1.37^{*}$ & & $-5.56^{* *}$ & $-5.69^{* *}$ \\
INFL & $-1.24^{*}$ & $-1.89^{*}$ & & $-12.00^{* *}$ & $-11.38^{* *}$ \\
GDPF & $-2.26^{*}$ & $-2.64^{* * *}$ & & $-7.00^{* *}$ & $-7.02^{* *}$ \\
GOV & $1.12^{*}$ & $1.21^{*}$ & & $-6.10^{* *}$ & $-10.10^{* *}$ \\
M2 & $0.20^{*}$ & $-0.44^{*}$ & & $-3.91^{* *}$ & $-6.01^{* *}$ \\
RUS & $-1.61^{*}$ & $-1.87^{*}$ & $-6.42^{* *}$ & $-6.44^{* *}$ \\
\hline
\end{tabular}

* denotes that the hypothesis that the variable contain unit root cannot be rejected at the 10 per cent level of significance.

** denotes the rejection of the hypothesis that the variable contain unit root at the 1 per cent level of significance.

*** denotes that the hypothesis that the variable contain unit root cannot be rejected at the 5 per cent level of significance.

\section{Unit Root Tests}

We use both the augmented Dickey-Fuller (ADF) test and the PhillipsPerron test for unit root tests. Table 3.2 reports the results of the unit root tests of all relevant variables in our models. For the level variables, both tests reveal that we cannot reject the presence of a unit root, which shows these variables are all nonstationary. On the other hand, the PhillipsPerron test rejects the null hypothesis of the presence of a unit root at the 1 percent level of significance for the first difference of all variables, while the ADF test rejects the null hypothesis at the 1 percent level of significance for the first difference of all variables except GDP. The ADF test cannot reject the presence of a unit root for the first difference time series of GDP. Here, we adopt the result of the Phillips-Perron test for GDP, and therefore assert that all variables in our models are the first order integrated variables, namely variables of I (1).

\section{Cointegration Tests}

Because all variables in our models are variables of I (1), we need to further test if there are cointegration vectors for each model. We implement VAR-based cointegration tests using the methodology developed in Johansen (1995). Table 3.3 reports the results of Johansen cointegration tests, which indicate that there is at least one cointegration vector for each VAR model. Therefore nonstationary data needs less concern in this study. In fact, as elaborated in Sims, Stock, and Watson (1990), when variables are cointegrated using a VAR in levels model is not misspecified, and the estimates are consistent. Some economists suggest that when one really doesn't know whether there is cointegration or what the cointegration vec- 
Table 3.3

Cointegration tests for alternative specifications

\begin{tabular}{|c|c|c|c|}
\hline Hypothesized No. of CE(s) & Eigenvalue & $\lambda$-Trace Statistics & $\lambda$-Max Statistics \\
\hline \multicolumn{4}{|c|}{ Model 1: Series: GDPF INFL REER GDP } \\
\hline None & 0.68 & $94.67 *$ & $62.30 *$ \\
\hline At most 1 & 0.26 & $32.38^{*}$ & 16.73 \\
\hline At most 2 & 0.19 & $15.65^{*}$ & 11.54 \\
\hline At most 3 & 0.07 & $4.11^{*}$ & $4.11^{*}$ \\
\hline \multicolumn{4}{|c|}{ Model 2: Series: GDPF INFL GOV REER GDP } \\
\hline None & 0.70 & $149.45^{*}$ & $65.79 *$ \\
\hline At most 1 & 0.56 & $83.66^{*}$ & $45.72^{*}$ \\
\hline At most 2 & 0.35 & $37.95^{*}$ & $23.93^{*}$ \\
\hline At most 3 & 0.17 & 14.01 & 10.02 \\
\hline At most 4 & 0.07 & $4.00^{*}$ & $4.00^{*}$ \\
\hline \multicolumn{4}{|c|}{ Model 3: Series: GDPF M2 INFL REER GDP } \\
\hline None & 0.69 & $137.91^{*}$ & $63.97 *$ \\
\hline At most 1 & 0.62 & 73.94* & $52.53 *$ \\
\hline At most 2 & 0.25 & 21.42 & 15.68 \\
\hline At most 3 & 0.10 & 5.73 & 5.70 \\
\hline At most 4 & 0.00 & 0.03 & 0.03 \\
\hline \multicolumn{4}{|c|}{ Model 4: Series: RUS GDPF INFL REER GDP } \\
\hline None & 0.70 & $154.51^{*}$ & $66.46^{*}$ \\
\hline At most 1 & 0.67 & $88.04 *$ & $60.79 *$ \\
\hline At most 2 & 0.27 & 27.25 & 17.00 \\
\hline At most 3 & 0.15 & 10.25 & 8.79 \\
\hline At most 4 & 0.03 & 1.47 & 1.47 \\
\hline
\end{tabular}

Note: Lags interval (in first difference): 1 to 3 .

* denotes rejection of the hypothesis at the 0.05 level of significance.

tor is, the VAR in levels approach is probably better than the approach that tests for cointegration, estimates cointegrating relations, and then estimates a vector error correction (VEC) model (Cochrane 2005). We follow the suggestion and conduct our study on the relationship between RMB real exchange rate and China's output by using VAR in levels model in the next section.

\subsection{Empirical Results}

This section comprises two subsections. The first subsection presents the empirical results derived from our VAR in levels models. The estimation results of the VAR models are given in the form of impulse response functions and variance decompositions, and based on those, the empirical analysis of the relationship between RMB real exchange rate and China's output is then conducted. In the second subsection, the robustness of the results obtained in the first subsection is investigated by adopting different ordering of variables, using VEC model specification, and substituting 
RUS for GDPF in the first three models as a proxy of external shock. We want to know whether the results change significantly or not when we make those changes.

\subsubsection{Results from the VAR in Levels Model}

In a VAR analysis, the dynamic interactions between the variables are usually investigated by impulse response functions or forecast error variance decompositions. In this subsection, we obtain our empirical results concerning the relationship between $\mathrm{RMB}$ real exchange rate and China's output by using these two instruments.

\section{Impulse Response Functions}

The impulse response functions (IRFs) display the responses of a particular variable to a one-time shock in each of the variables in the system. Figure 3.3 and figure 3.4 plot the IRFs of GDP and REER respectively calculated from four VAR models. By investigating those IRFs graphs, the following results can be drawn:

First, when one standard deviation positive (appreciation) shock to REER takes place, there is an obvious decline of GDP, indicating that $\mathrm{RMB}$ real rate shocks have a negative impact on China's output. From the 8 th quarter, the contractionary effect is weakened to some extent but obviously still exists. After 18 quarters, the impact of RMB real rate shock on output turns to be positive. This effect of RMB real appreciation occurs in all models estimated, suggesting the robustness of the result. This result is in contrast with that of, say, Edwards (1986) and Kamin and Rogers (2000). In Edwards (1986), for 12 countries studied, devaluations (revaluations) were contractionary (expansionary) in the short-term, but after one year devaluations turned out to be expansionary. In Kamin and Rogers (2000) devaluations (revaluations) were contractionary (expansionary) in shortterm as well as in medium-term in Mexico.

Second, in model 4, which includes RUS, the contractionary effect of positive shocks to REER on GDP is significantly less than that in other three models that do not include RUS. The former is only about half of the latter. On the other hand, shocks to RUS have a remarkable contractionary effect on GDP; the magnitude of the effect is even larger than that of REER shocks. These two findings seem to indicate that on one hand the capital control in China is less efficient than we thought. On the other, capital flows have a significant impact on the Chinese economy, which is even larger than the impact of trade (the impact of REER) on the economy. ${ }^{11}$ In other words, after accounting for the effect of international finance

11. The impact of a rise in RUS on the Chinese economy may function through the following channel: a rise in RUS results in a decline in U.S. demands, which in turn causes the demand for China's export to decline. But because we have entered GDPF into model 4, the influence of this channel has already been controlled. 


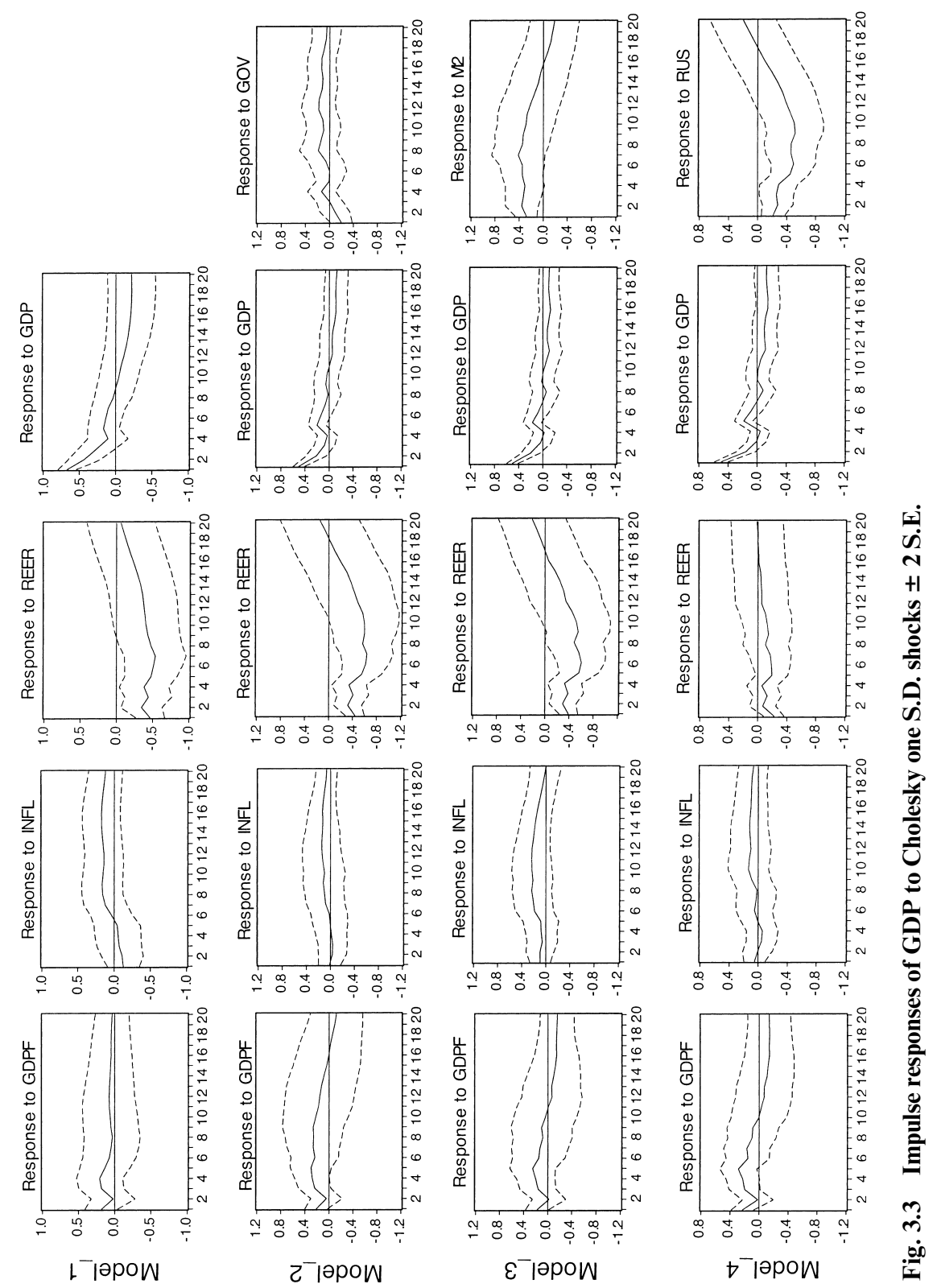



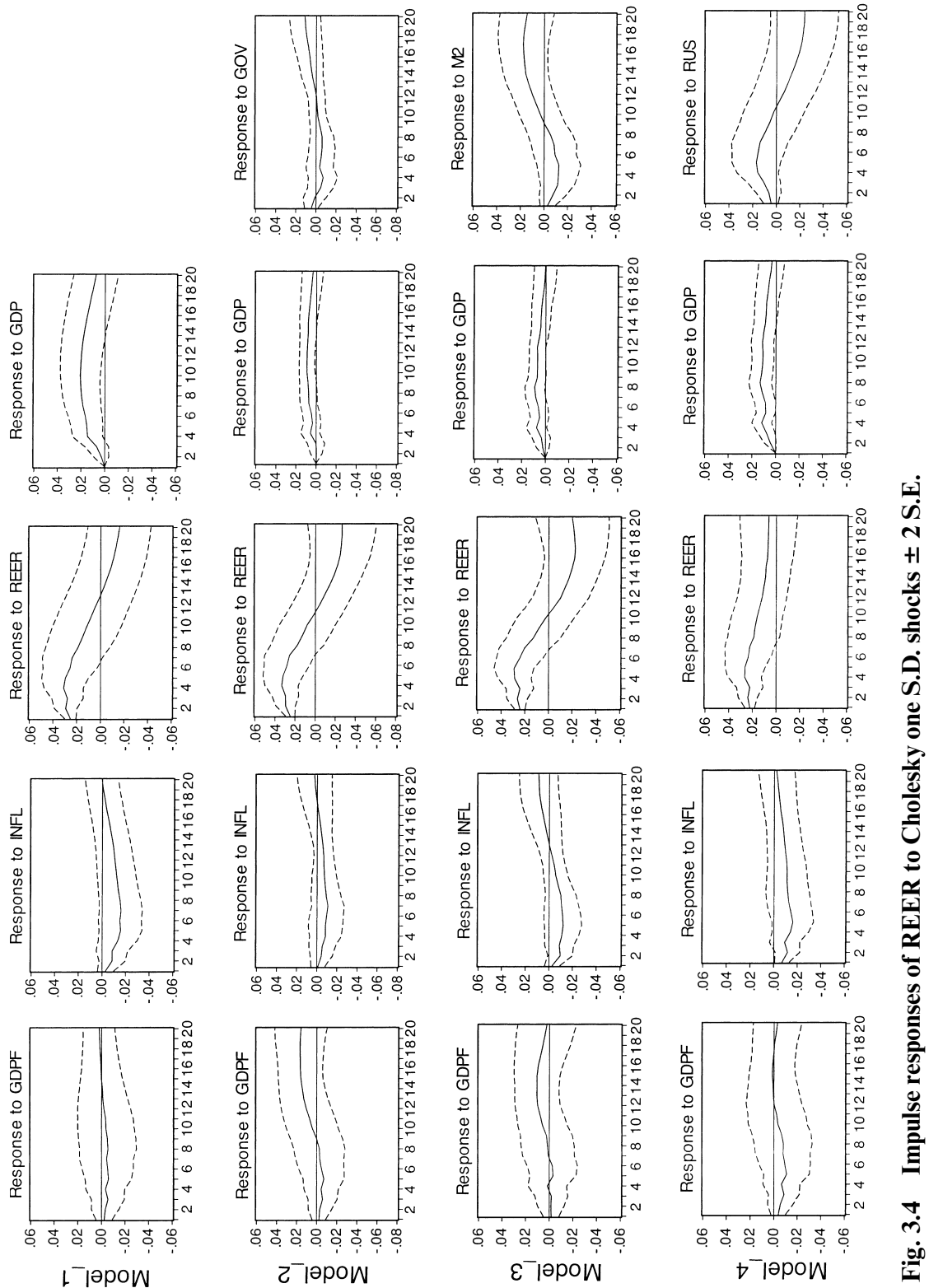
linkage, the effect of RMB real appreciation on China's real economy may be smaller than what we have expected.

Third, one standard deviation shock to GDP has no obvious impact on REER. After the 3rd quarter, the shock causes REER raise for some extent. This effect of output shock occurs in all models estimated, suggesting the robustness of the result. Because the measure of the IRFs graphs of REER is only about one tenth relative to the measure of those of GDP, we think that the magnitude of impact of output shocks on RMB real rate is much less than that of the impact of RMB real rate shocks on output.

Fourth, the impact of shocks to other variables virtually accords with the economic intuition. For example, an increase in money supply has an obvious expansionary effect and causes the real exchange rate depreciation in short-term. GDPF shocks have expansionary effect too; an increases in government spending results in RMB real appreciation in first 2 quarters, and inflation shocks cause a decline of GDP in short-term. An important exception is the effect of INFL shocks on REER. An increase in inflation causes real exchange rate depreciation. We should expect that an increase in inflation causes the RMB real exchange rate to appreciate, because the nominal rate of RMB has been very steady since 1997. In addition, an increase in government spending causes GDP to drop in the first two quarters. One possible explanation of this may be that in the short run government spending has a strong crowding-out effect in China.

In summary, the analyses based on IRFs suggest that the RMB real appreciation shock has contractionary effect on China's output. After controlling the influence of other variables, the RMB real appreciation shock still causes GDP to decline, which excludes the spurious correlation between RMB real exchange rate and China's output. The empirical results also seem to support the guess that the direction of the causality between the RMB real rate and China's output runs from the former to the latter. Finally, the external shocks have remarkable effects on China's output. In particular, U.S. interest rate shocks have a significant impact on China's cyclical output. When the effect of RUS is included in VAR model, the effect of REER turns out to be weaker for certain degree.

\section{Variance Decompositions}

The IRFs provide a useful tool to assess the direction as well as the magnitude of response of a variable to various kinds of shocks. However, the variance decompositions give the fraction of the forecast error variance for each variable that is attributable to its own shocks and to shocks in the other variables in the system, so allow us to appraise the relative importance of the contribution of different shocks to the variance of a particular variable. Table 3.4 provides the variance decompositions of GDP and RMB real exchange rate from four VAR models. The following results emerge from table 3.4 . 


\begin{tabular}{|c|c|c|c|c|c|c|c|c|c|c|c|c|}
\hline $\mathrm{T}$ & \multicolumn{2}{|c|}{ S.E. } & \multicolumn{2}{|c|}{ GDPF } & \multicolumn{2}{|c|}{ INFL } & \multicolumn{2}{|c|}{ REER } & \multicolumn{2}{|c|}{ GDP } & & \\
\hline \multicolumn{13}{|c|}{ Model 1} \\
\hline 1 & 0.9 & 0.6 & 4.6 & 0.8 & 2.4 & 1.4 & 30.7 & 97.8 & 62.3 & 0.0 & & \\
\hline 2 & 1.2 & 0.7 & 3.3 & 1.0 & 2.9 & 5.1 & 33.0 & 93.4 & 60.8 & 0.5 & & \\
\hline 3 & 1.5 & 0.7 & 4.9 & 1.8 & 2.6 & 6.1 & 40.3 & 89.9 & 52.2 & 2.2 & & \\
\hline 4 & 1.6 & 0.7 & 7.1 & 1.5 & 2.5 & 8.6 & 44.5 & 83.1 & 45.9 & 6.8 & & \\
\hline 8 & 1.8 & 1.3 & 5.0 & 2.0 & 3.0 & 14.8 & 63.4 & 65.8 & 28.5 & 17.4 & & \\
\hline 12 & 1.8 & 1.6 & 4.4 & 2.0 & 4.9 & 16.5 & 68.1 & 53.8 & 22.6 & 27.7 & & \\
\hline 20 & 1.9 & 1.8 & 3.9 & 1.7 & 8.2 & 15.2 & 63.2 & 49.4 & 24.8 & 33.8 & & \\
\hline $\mathrm{T}$ & \multicolumn{2}{|c|}{ S.E. } & \multicolumn{2}{|c|}{ GDPF } & \multicolumn{2}{|c|}{ INFL } & \multicolumn{2}{|c|}{ REER } & \multicolumn{2}{|c|}{ GDP } & \multicolumn{2}{|c|}{ GOV } \\
\hline \multicolumn{13}{|c|}{ Model 2} \\
\hline 1 & 1.0 & 0.6 & 8.4 & 0.8 & 0.0 & 0.2 & 36.7 & 96.0 & 47.5 & 0.0 & 7.3 & 3.1 \\
\hline 2 & 1.3 & 0.6 & 6.7 & 1.0 & 0.2 & 1.3 & 43.2 & 96.3 & 43.1 & 0.0 & 6.9 & 1.4 \\
\hline 3 & 1.5 & 0.7 & 11.0 & 2.0 & 0.3 & 2.0 & 50.6 & 94.3 & 32.9 & 0.0 & 5.1 & 1.8 \\
\hline 4 & 1.7 & 0.8 & 16.0 & 2.0 & 0.3 & 3.2 & 51.4 & 91.7 & 26.7 & 0.9 & 5.7 & 2.4 \\
\hline 8 & 1.8 & 1.2 & 16.0 & 2.1 & 0.7 & 6.6 & 68.0 & 85.9 & 12.3 & 2.6 & 3.5 & 2.7 \\
\hline 12 & 1.9 & 1.4 & 14.0 & 4.0 & 1.7 & 8.4 & 72.4 & 78.8 & 8.1 & 6.2 & 3.9 & 2.6 \\
\hline 20 & 2.1 & 1.8 & 13.0 & 15.6 & 3.5 & 5.2 & 70.2 & 68.6 & 8.4 & 6.0 & 5.3 & 4.7 \\
\hline $\mathrm{T}$ & \multicolumn{2}{|c|}{ S.E. } & \multicolumn{2}{|c|}{ GDPF } & \multicolumn{2}{|c|}{ INFL } & \multicolumn{2}{|c|}{ REER } & \multicolumn{2}{|c|}{ GDP } & \multicolumn{2}{|c|}{ M2 } \\
\hline \multicolumn{13}{|c|}{ Model 3} \\
\hline 1 & 1.0 & 0.0 & 5.8 & 0.5 & 1.6 & 1.4 & 29.4 & 96.3 & 48.2 & 0.0 & 15.0 & 1.8 \\
\hline 2 & 1.3 & 0.0 & 3.9 & 0.3 & 2.1 & 6.8 & 30.7 & 88.0 & 37.3 & 0.3 & 25.9 & 4.5 \\
\hline 3 & 1.5 & 0.0 & 5.3 & 0.4 & 1.8 & 7.9 & 36.4 & 82.3 & 27.6 & 0.7 & 28.9 & 8.8 \\
\hline 4 & 1.7 & 0.0 & 7.3 & 0.3 & 1.9 & 8.7 & 37.9 & 78.6 & 22.5 & 2.1 & 30.4 & 10.2 \\
\hline 8 & 1.8 & 0.0 & 6.1 & 0.5 & 4.8 & 12.0 & 51.5 & 72.5 & 9.9 & 4.3 & 27.7 & 10.7 \\
\hline 12 & 1.9 & 0.1 & 4.6 & 3.1 & 7.5 & 12.1 & 54.8 & 66.8 & 7.3 & 6.4 & 25.8 & 11.6 \\
\hline 20 & 2.1 & 0.1 & 6.5 & 5.5 & 9.0 & 8.9 & 52.3 & 59.9 & 7.8 & 4.0 & 24.4 & 21.6 \\
\hline $\mathrm{T}$ & \multicolumn{2}{|c|}{ S.E. } & \multicolumn{2}{|c|}{ GDPF } & \multicolumn{2}{|c|}{ INFL } & \multicolumn{2}{|c|}{ REER } & \multicolumn{2}{|c|}{ GDP } & & \\
\hline & & & & & & Moc & & & & & & \\
\hline 1 & 0.5 & 1.0 & 13.2 & 2.6 & 0.7 & 8.2 & 12.4 & 85.3 & 61.9 & 0.0 & 11.8 & 3.9 \\
\hline 2 & 0.8 & 1.2 & 10.5 & 3.4 & 0.5 & 13.3 & 10.7 & 77.1 & 53.5 & 1.5 & 24.7 & 4.7 \\
\hline 3 & 0.9 & 1.5 & 14.8 & 5.5 & 0.8 & 12.2 & 11.2 & 70.7 & 42.8 & 3.7 & 30.4 & 7.9 \\
\hline 4 & 1.0 & 1.7 & 18.5 & 4.7 & 1.1 & 13.1 & 9.5 & 63.9 & 35.1 & 6.3 & 35.8 & 12.0 \\
\hline 8 & 1.2 & 1.8 & 14.8 & 6.3 & 0.6 & 15.1 & 9.3 & 54.6 & 16.3 & 8.6 & 58.9 & 15.4 \\
\hline 12 & 1.4 & 1.9 & 10.2 & 5.6 & 2.2 & 16.5 & 7.8 & 52.6 & 11.3 & 12.1 & 68.5 & 13.1 \\
\hline 20 & 1.7 & 2.0 & 12.0 & 4.1 & 4.1 & 13.5 & 6.6 & 40.4 & 12.8 & 11.6 & 64.6 & 30.4 \\
\hline
\end{tabular}

Notes: The two columns below a variable give the fraction of the forecast error variance for GDP and REER that is attributable to shocks to the variable at the given forecast horizon, with the bold column in left indicating the fraction for GDP. The columns below "S.E." contain the forecast error of GDP and REER at the given forecast horizon. 
First, concerning the source of variation in GDP forecast error, for those models that do not include RUS, "own shocks" is the first most important source at the horizons of the first and second quarters, while RMB real exchange rate shock is the second most important source. Beginning from the third quarter, however, the RMB real exchange rate shocks become the first most important source of variation in GDP, and accounts for 36-70 percent of the GDP forecast error variance in models 2 and 3. In the medium and long-term horizon, "own shocks" is the second most important source in model 1, which accounts for about 24 percent of the GDP error variance, while the contributions of "own shocks" in model 2 and 3 decrease greatly, and only account for about 8 percent of the GDP error variance. In contrast, shocks to GDPF and M2 turn out to be the second most important source of the GDP error variance in model 2 and 3 respectively, in the medium and long-term horizon, and account for about 14 percent and 26 percent of the GDP error variance respectively.

Second, in model 4, which includes RUS, "own shocks" to GDP is the first most important source of the GDP error variance only at the horizons of the first, second, and third quarters. Beginning from the 4th quarter, however, the RUS shocks become the first most important and predominant source of variation in GDP, accounting for 36-69 percent of the GDP error variance, while in the long-term horizon "own shocks" and GDPF shocks turn to be second and the third most important source of the GDP error variance, accounting for about 13 percent and 11 percent respectively. In contrast, REER shocks become the fourth important source of variation in GDP, only accounting for 7 percent of variation in the longterm horizon. When RUS is included in VAR model, the power of REER shocks in explaining the error variance of GDP has significantly declined. This result is consistent with what we obtained in IRFs analysis.

Third, in the source of variation in RMB real exchange rate forecast error, "own shocks" is the first most important and predominant source, accounting for 63-98 percent of the forecast error variance at the horizons of the first to fourth quarters, and 40-70 percent after eight quarters. On the other hand, the contribution of GDP shocks to the error variance of REER is negligible at the horizons of the first to fourth quarters. In the medium- and long-term horizon, the contribution of GDP shocks to the error variance of REER is about 30 percent in model 1, but drops by a large margin to under 7 percent in model 2 and model 3 and about 12 percent in model 4. On the contrary, shocks to M2, GDPF, and RUS in the other three models all have relatively large contribution to the error variance of REER. What merits attention is that GOV has very little contribution to the error variance of REER.

In summary, the analyses based on the variance decompositions suggest that (a) the shocks to the RMB real exchange rate have a large contribution to the variation in China's output in models that do not include the U.S. in- 
terest rate, and some contribution to the variation in China's output in the model that includes the U.S. interest rate, suggesting the possibility that the spurious correlation between the RMB real exchange rate and China's output can be excluded; (b) except for the basic model (Model 1), the shocks to GDP have small contribution to the variation in RMB real exchange rate, and the contribution is negligible at the horizons of the first to fourth quarters, suggesting the possibility of reverse causation running from the GDP to the RMB real exchange rate can be excluded; and (c) when the U.S. interest rate is included in VAR model, the power of REER shocks in explaining the error variance of GDP significantly declines.

\subsubsection{Robustness Analysis}

The results obtained in the previous subsection may be specific to the selected ordering of endogenous variables. Therefore, it is interesting to estimate our VAR models with different and plausible ordering. In addition, because all variables in our models are variables of I (1) and there are cointegration vectors for each model, it is worth trying to check the results obtained from the VAR in level models with those obtained from the cointegration restricted VAR models, that is, the VEC models. ${ }^{12}$ Furthermore, the results of previous subsection suggest that the magnitude of the effect of the RMB exchange rate shocks on China's output is diminished remarkably by including the U.S. interest rate in the VAR model, therefore it is also interesting to substitute RUS for GDPF as a proxy of external shock in our first three VAR models. In this subsection we therefore investigate the robustness of the results as regards these three points.

\section{Different Ordering}

Kamin and Rogers (2000) adopt orderings a little bit different from ours in their VAR models. Except for GDPF, variables in our four VAR models are ordered as in Kamin and Rogers (2000) as follows: model 1: REER $\rightarrow$ INFL $\rightarrow$ GDP; model 2: GOV $\rightarrow$ REER $\rightarrow$ INFL $\rightarrow$ GDP; model 3: REER $\rightarrow \mathrm{M} 2 \rightarrow \mathrm{INFL} \rightarrow \mathrm{GDP}$; and model $4: \mathrm{RUS} \rightarrow \mathrm{REER} \rightarrow \mathrm{INFL} \rightarrow \mathrm{GDP}$. If we relax the assumption of price stickiness in the short run, the above orderings seem plausible. For example, in model 1, an appreciation of real exchange rate shifts demand away from nontraded goods and decreases the price of nontraded goods and the general price level for a given level of nominal exchange rate. The adjustment of the price level then causes the change of output.

We reestimate our four VAR models by adopting the above orderings and find that the results are quite similar to those of previous subsection. Owing to the space limitation, we only present the impulse response func-

12. Some economists argue that it is appropriate to estimate VEC model when variables are I (1) and there are cointegrating relations between them (Engle and Granger 1987). 
tions of GDP from the four VAR models using orderings adopted by Kamin and Rogers (2000) (figure 3.5).

\section{Results from VEC Model}

The VEC models to be estimated have following forms:

$$
\Delta Y_{t}^{l}=\alpha^{l} E C M_{t-1}^{l}+\sum_{i=l}^{k_{l}-1} \Gamma_{i}^{l} \Delta Y_{t-i}^{l}+\varepsilon_{t}^{l}, \varepsilon_{t}^{l} \sim \operatorname{IID}\left[o^{l}, \Omega^{l}\right], l=\overline{1,4}
$$

where $E C M_{t-l}^{l}=\beta^{l^{\prime}} Y_{t-1}^{l}$ is the error correction terms, reflecting the long-run equilibrium relationship between the variables. $\beta^{\prime \prime}$ is the matrix of cointegration vectors. The coefficient vector $\alpha^{l}$ reflects how fast the deviation from the long-run equilibrium is corrected through a series of partial shortrun adjustments. $\Gamma_{i}^{l}$ is parameter matrix of variables in differences, the elements of these matrices reflect the short-term effect of the variables on a dependent variable.

We estimate four VEC models adopting the same orderings of the previous subsection. By investigating the estimation results of four VEC models, we find that the IRFs of VEC models are very similar with those of VAR models in direction and dynamic path of the responses. The results of variance decompositions are basically similar too. But one difference is: the effect of various shocks in VEC models case seems more lasting than that in VAR models. Taking the response of GDP to the REER shocks as an example the contractionary effect of an appreciation of REER sustains longer before the expansionary effect appears. Because restricted by space, we only provide the results of variance decompositions of GDP and REER and impulse response functions of GDP from the VEC models (table 3.5 and figure 3.6).

\section{Substitution RUS for GDPF in VAR Model}

When we substitute RUS for GDPF in VAR Models and reestimate the first three VAR models of the previous subsection we find that comparing the original models using GDPF as proxy variable for external shocks: (a) the IRFs of three new VAR models are similar with those of model 4 of the previous subsection - the magnitude of the effect of RMB exchange rate shocks on China's output is diminished, especially in medium and longterm; (b) the expansionary effect of REER shocks appears earlier; (c) concerning the source of variation in GDP forecast error, in all three new VAR models the RUS shocks become the most important and predominant source of variation in GDP error variance respectively. The contributions of "own shocks" and M2 to variation in GDP have exceeded the contribution of REER in the second and third new models; (d) the effects of other shocks on GDP are similar between new models and original ones. Figure 3.7 and table 3.6 provide IRFs and variance decompositions of GDP from 


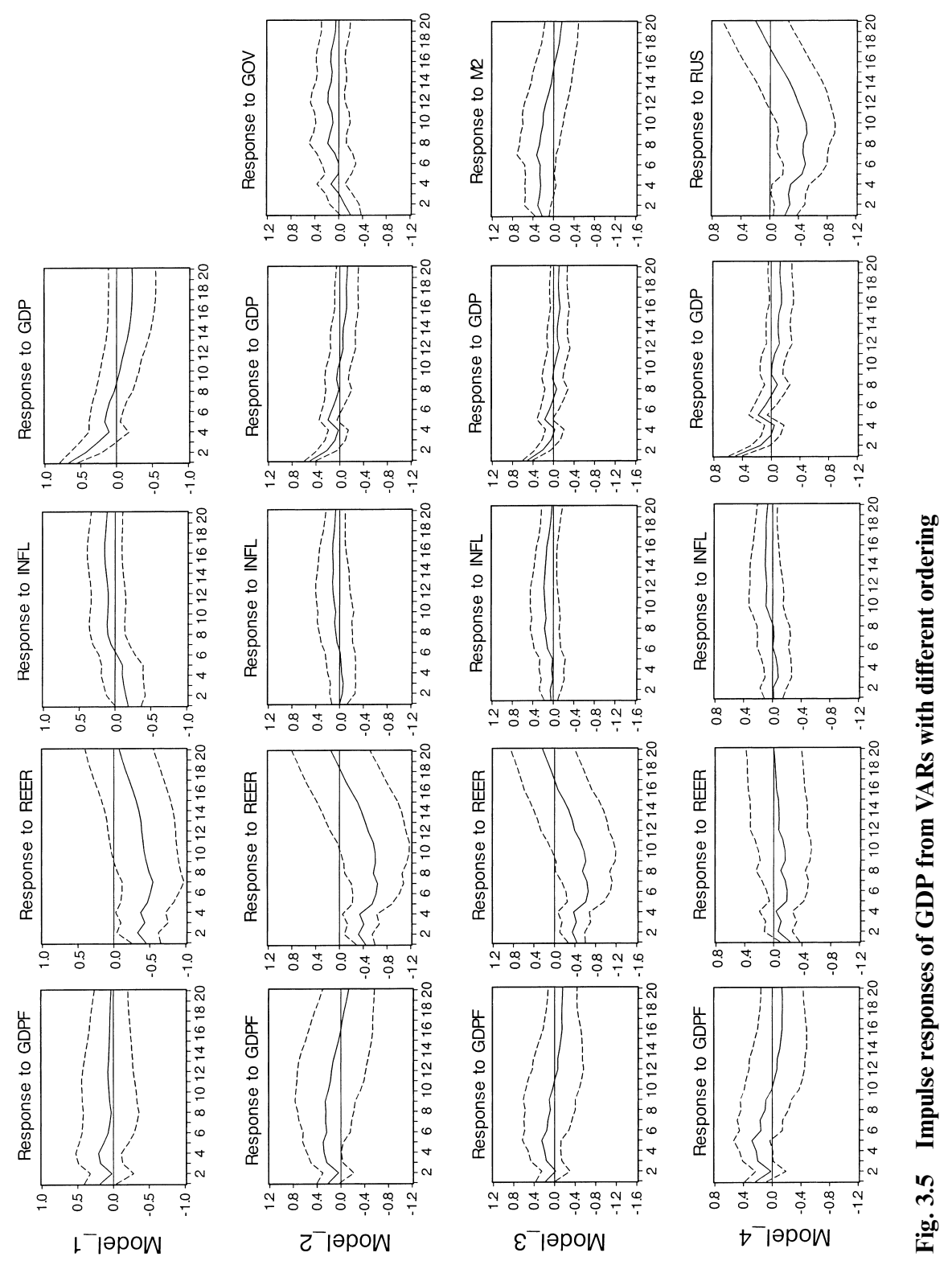




\begin{tabular}{|c|c|c|c|c|c|c|c|c|c|c|c|c|}
\hline $\mathrm{T}$ & \multicolumn{2}{|c|}{ S.E. } & \multicolumn{2}{|c|}{ GDPF } & \multicolumn{2}{|c|}{ INFL } & \multicolumn{2}{|c|}{ REER } & \multicolumn{2}{|c|}{ GDP } & & \\
\hline \multicolumn{13}{|c|}{ Model 1} \\
\hline 1 & 1.0 & 0.6 & 2.7 & 0.2 & 3.1 & 2.8 & 30.4 & 97.1 & 63.8 & 0.0 & & \\
\hline 2 & 1.5 & 0.7 & 1.7 & 0.1 & 4.2 & 8.4 & 29.9 & 91.0 & 64.2 & 0.6 & & \\
\hline 3 & 2.0 & 0.7 & 2.0 & 0.2 & 4.0 & 11.1 & 35.2 & 86.6 & 58.8 & 2.2 & & \\
\hline 4 & 2.5 & 0.8 & 2.8 & 0.1 & 4.5 & 14.6 & 39.0 & 79.4 & 53.8 & 5.9 & & \\
\hline 8 & 3.3 & 1.9 & 1.6 & 0.0 & 3.7 & 22.7 & 59.9 & 67.6 & 34.8 & 9.7 & & \\
\hline 12 & 4.0 & 2.8 & 1.1 & 0.1 & 3.3 & 24.9 & 70.1 & 63.8 & 25.4 & 11.2 & & \\
\hline 20 & 5.1 & 4.2 & 0.8 & 0.1 & 2.8 & 26.2 & 78.6 & 61.5 & 17.8 & 12.1 & & \\
\hline $\mathrm{T}$ & \multicolumn{2}{|c|}{ S.E. } & \multicolumn{2}{|c|}{ GDPF } & \multicolumn{2}{|c|}{ INFL } & \multicolumn{2}{|c|}{ REER } & \multicolumn{2}{|c|}{ GDP } & \multicolumn{2}{|c|}{ GOV } \\
\hline \multicolumn{13}{|c|}{ Model 2} \\
\hline 1 & 1.0 & 0.6 & 8.3 & 0.5 & 0.1 & 0.4 & 37.8 & 95.3 & 45.9 & 0.0 & 7.8 & 3.8 \\
\hline 2 & 1.4 & 0.6 & 6.7 & 0.8 & 0.2 & 1.7 & 45.6 & 95.7 & 40.6 & 0.0 & 6.9 & 1.8 \\
\hline 3 & 1.8 & 0.7 & 11.9 & 2.0 & 0.3 & 2.3 & 53.2 & 94.2 & 29.7 & 0.0 & 5.0 & 1.5 \\
\hline 4 & 2.0 & 0.7 & 18.4 & 2.1 & 0.3 & 3.0 & 53.6 & 92.7 & 22.6 & 0.4 & 5.1 & 1.8 \\
\hline 8 & 2.4 & 1.3 & 23.0 & 6.0 & 0.1 & 3.1 & 67.0 & 88.8 & 7.6 & 0.6 & 2.2 & 1.5 \\
\hline 12 & 2.7 & 1.5 & 27.2 & 10.0 & 0.1 & 2.6 & 67.3 & 84.9 & 3.5 & 1.0 & 2.0 & 1.6 \\
\hline 20 & 3.8 & 1.6 & 33.0 & 11.3 & 0.1 & 2.4 & 63.2 & 82.9 & 1.6 & 1.2 & 2.2 & 2.1 \\
\hline $\mathrm{T}$ & \multicolumn{2}{|c|}{ S.E. } & \multicolumn{2}{|c|}{ GDPF } & \multicolumn{2}{|c|}{ INFL } & \multicolumn{2}{|c|}{ REER } & \multicolumn{2}{|c|}{ GDP } & \multicolumn{2}{|c|}{ M2 } \\
\hline \multicolumn{13}{|c|}{ Model 3} \\
\hline 1 & 1.0 & 0.0 & 4.4 & 0.7 & 2.3 & 1.8 & 29.9 & 94.8 & 46.4 & 0.0 & 17.0 & 2.7 \\
\hline 2 & 1.5 & 0.0 & 3.0 & 0.4 & 2.9 & 7.0 & 32.1 & 86.2 & 33.9 & 0.2 & 28.1 & 6.3 \\
\hline 3 & 2.0 & 0.0 & 3.3 & 0.4 & 2.9 & 8.2 & 39.1 & 79.6 & 23.2 & 0.3 & 31.5 & 11.5 \\
\hline 4 & 2.5 & 0.0 & 4.5 & 0.3 & 3.1 & 8.9 & 42.0 & 76.3 & 17.4 & 1.0 & 32.9 & 13.5 \\
\hline 8 & 3.3 & 0.0 & 5.0 & 0.3 & 4.1 & 9.8 & 55.8 & 70.5 & 5.6 & 0.7 & 29.5 & 18.8 \\
\hline 12 & 4.1 & 0.1 & 5.2 & 0.3 & 4.6 & 10.3 & 58.6 & 68.1 & 2.6 & 0.6 & 29.0 & 20.7 \\
\hline 20 & 5.5 & 0.1 & 5.6 & 0.9 & 4.8 & 10.6 & 58.6 & 66.8 & 1.3 & 0.7 & 29.6 & 21.0 \\
\hline $\mathrm{T}$ & \multicolumn{2}{|c|}{ S.E. } & \multicolumn{2}{|c|}{ GDPF } & \multicolumn{2}{|c|}{ INFL } & \multicolumn{2}{|c|}{ REER } & \multicolumn{2}{|c|}{ GDP } & & \\
\hline & & & & & & $\mathrm{Mod}$ & & & & & & \\
\hline 1 & 0.5 & 1.0 & 13.6 & 1.5 & 1.0 & 10.4 & 12.0 & 81.5 & 58.9 & 0.0 & 14.6 & 6.6 \\
\hline 2 & 0.7 & 1.5 & 10.4 & 1.4 & 0.7 & 17.1 & 10.3 & 71.1 & 47.8 & 1.4 & 30.8 & 9.0 \\
\hline 3 & 1.1 & 2.0 & 14.9 & 2.0 & 0.6 & 17.0 & 11.3 & 63.6 & 34.1 & 2.9 & 39.2 & 14.5 \\
\hline 4 & 1.3 & 2.5 & 19.4 & 1.3 & 0.6 & 18.4 & 9.7 & 55.8 & 24.7 & 4.1 & 45.7 & 20.4 \\
\hline 8 & 2.0 & 3.5 & 17.1 & 0.5 & 0.3 & 22.6 & 12.4 & 43.5 & 7.1 & 2.9 & 63.2 & 30.5 \\
\hline 12 & 2.4 & 4.4 & 12.3 & 0.9 & 1.2 & 26.3 & 13.9 & 39.6 & 2.9 & 2.4 & 69.7 & 30.8 \\
\hline 20 & 2.9 & 5.6 & 8.1 & 2.2 & 2.7 & 31.3 & 14.3 & 37.9 & 1.2 & 2.0 & 73.7 & 26.6 \\
\hline
\end{tabular}

Notes: The two columns below a variable give the fraction of the forecast error variance for GDP and REER that is attributable to shocks to the variable at the given forecast horizon, with the black column in left indicating the fraction for GDP. The columns below "S.E." contain the forecast error of GDP and REER at the given forecast horizon. 

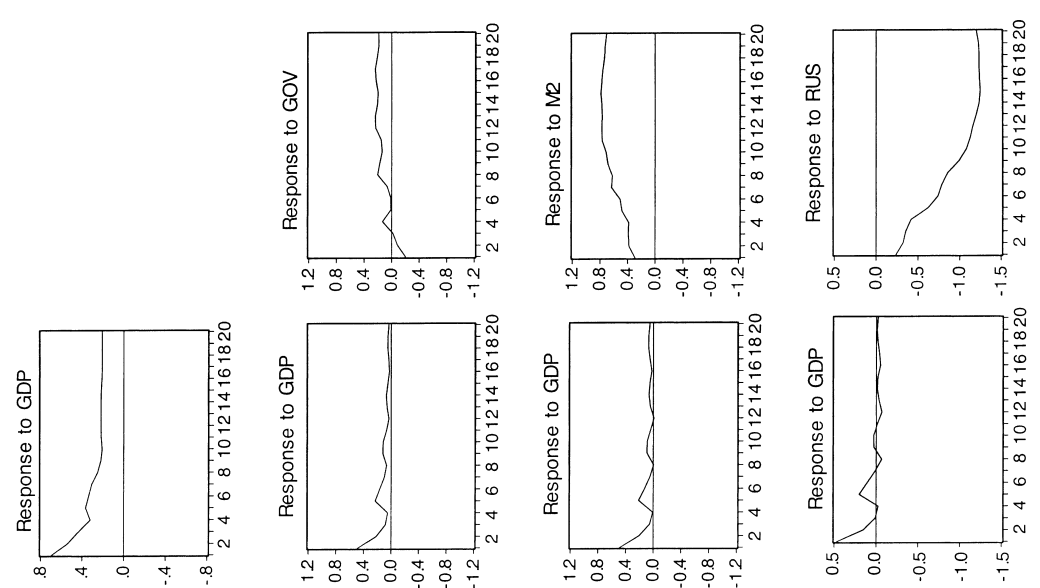

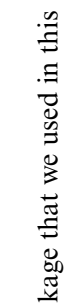
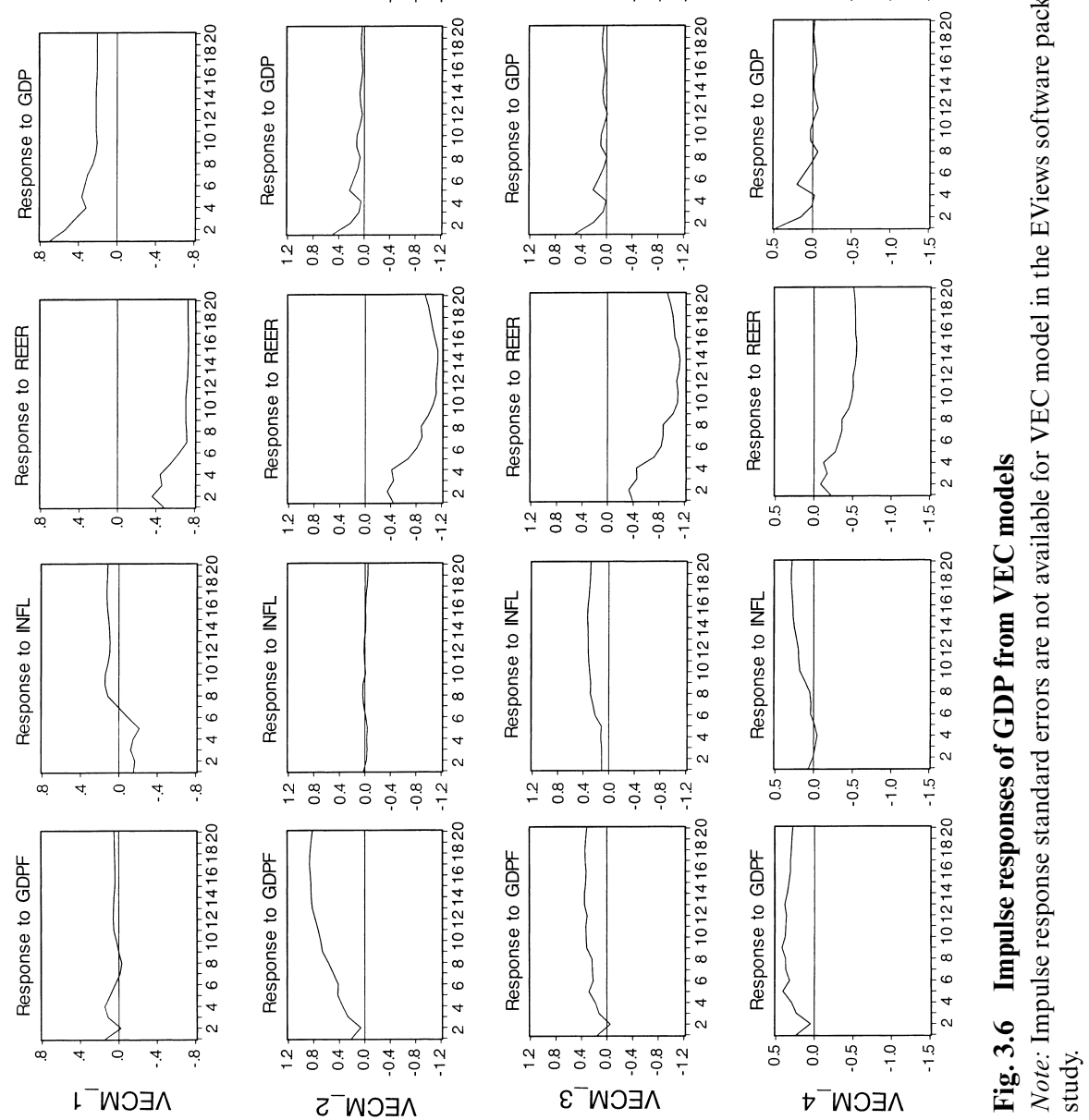

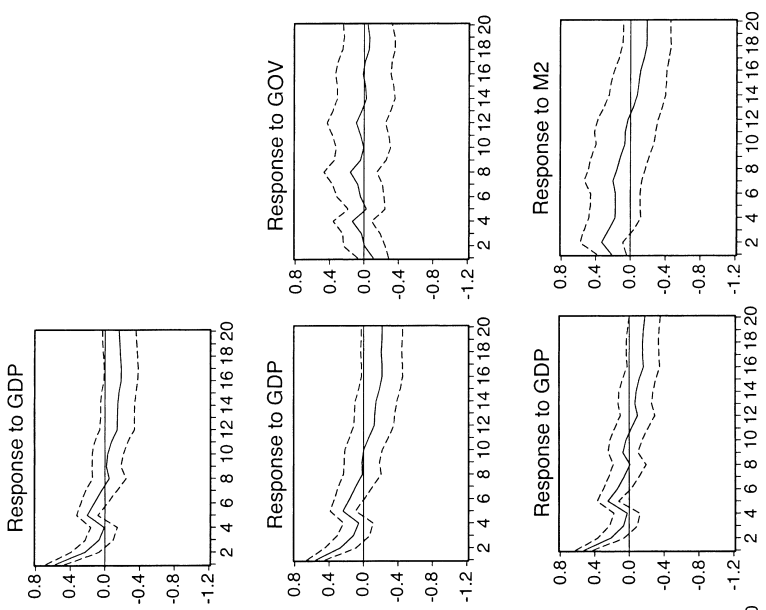

告 
Table 3.6

Variance decomposition of GDP from VAR models with RUS

\begin{tabular}{|c|c|c|c|c|c|c|}
\hline $\mathrm{T}$ & S.E. & RUS & INFL & REER & GDP & \\
\hline \multicolumn{7}{|c|}{ Model 1} \\
\hline 1 & 0.5 & 6.8 & 0.1 & 24.4 & 68.8 & \\
\hline 2 & 0.8 & 10.1 & 3.7 & 23.4 & 62.8 & \\
\hline 3 & 0.9 & 13.7 & 6.0 & 26.2 & 54.18 & \\
\hline 4 & 1.0 & 18.2 & 6.4 & 25.8 & 49.6 & \\
\hline 8 & 1.2 & 46.9 & 2.7 & 26.9 & 23.6 & \\
\hline 12 & 1.4 & 58.0 & 2.3 & 23.4 & 16.2 & \\
\hline 20 & 1.7 & 55.7 & 4.7 & 20.1 & 19.6 & \\
\hline $\mathrm{T}$ & S.E. & RUS & INFL & REER & GDP & GOV \\
\hline \multicolumn{7}{|c|}{ Model 2} \\
\hline 1 & 0.6 & 8.0 & 0.0 & 26.6 & 63.1 & 2.3 \\
\hline 2 & 0.8 & 9.8 & 5.9 & 23.9 & 58.7 & 1.7 \\
\hline 3 & 0.9 & 13.0 & 10.3 & 25.2 & 49.9 & 1.5 \\
\hline 4 & 1.0 & 16.5 & 11.4 & 24.3 & 44.4 & 3.4 \\
\hline 8 & 1.2 & 42.8 & 7.0 & 23.4 & 23.7 & 3.1 \\
\hline 12 & 1.3 & 59.1 & 4.7 & 17.6 & 16.2 & 2.4 \\
\hline 20 & 1.6 & 54.9 & 7.6 & 16.5 & 19.0 & 2.1 \\
\hline $\mathrm{T}$ & S.E. & RUS & INFL & REER & GDP & M2 \\
\hline \multicolumn{7}{|c|}{ Model 3} \\
\hline 1 & 0.5 & 7.8 & 0.1 & 22.3 & 59.6 & 10.2 \\
\hline 2 & 0.8 & 8.6 & 0.8 & 18.3 & 48.4 & 23.9 \\
\hline 3 & 0.9 & 11.7 & 2.2 & 18.9 & 39.9 & 27.3 \\
\hline 4 & 1.0 & 14.5 & 2.5 & 18.3 & 36.3 & 28.4 \\
\hline 8 & 1.1 & 42.9 & 1.6 & 16.7 & 20.1 & 18.7 \\
\hline 12 & 1.3 & 60.6 & 1.1 & 11.7 & 13.6 & 13.0 \\
\hline 20 & 1.6 & 57.9 & 1.9 & 12.1 & 14.3 & 13.9 \\
\hline
\end{tabular}

Notes: The column below a variable gives the fraction of the forecast error variance for GDP that is attributable to shocks to the variable at the given forecast horizon. The column below "S.E." contains the forecast error of GDP at the given forecast horizon.

the three new VAR models, with RUS replacing GDPF as a proxy variable of external shocks.

In summary, the robustness analysis confirms that our basic result, namely that the shocks to RMB real exchange rate have a contractionary effect on China's output, essentially does not change even if we adopt the orderings of Kamin and Rogers (2000) or use VEC model in our model specification. But after including the international finance linkage of the Chinese economy, the effect of REER shock on China's output and the power of REER shocks in explaining the changes of China's output turn to be relatively small, while the U.S. interest rate shock has relatively large 
effect on China's output, the magnitude of its effect exceeding that of RMB exchange rate shocks.

\subsection{Conclusion}

This paper has investigated the relationship between the RMB real exchange rate and China's output by using the VAR model technique. The empirical analysis reveals several interesting findings. First, even after source of spurious correlation is controlled for, $\mathrm{RMB}$ real appreciation has led to a decline in China's output, suggesting that currency appreciations have been contractionary in China, as traditional open economy macroeconomics forecasts. Second, when the international finance linkage of Chinese economy is accounted for, the effect of RMB real exchange rate shocks on China's output and the power of the shocks in explaining the change of China's output are relatively small, while the effect of U.S. interest rate shocks on China's output is relatively large. The intuition behind this finding may be that the effectiveness of China's capital controls has eroded over time and the scales of capital inflows and outflows have become large enough that external shocks through international finance channels have significant influence on the Chinese economy, exceeding the influence of external shocks through international trade channels. Third, besides shocks to RMB real exchange rate and the U.S. interest rate, shocks to domestic money supply and foreign demand all have important effects on China's output. However, government spending shocks have less power in explaining the change of China's output.

The conclusion that currency appreciations have been contractionary in China is remarkably different from those made by similar empirical works on developing countries. The possible explanations of this difference are as follows. First, in the existing research on contractionary devaluations effect in developing countries, devaluations usually take place under an abnormal environment of currency or financial crisis, and thus have been associated with economic recession, but RMB devaluations did not happen in case of currency or financial crisis until now. Second, the urban economic reform begun in the early 1990s has made many people lose their jobs and traditional benefits of medicare, pensions, education, and so on, which has strengthened the motive of precautionary saving of households in urban and township areas. Under that situation, the income reallocation effect as well as the real cash balance and the real wealth effects of currency appreciation may not play a very great role.

Third, China has absorbed a large amount of foreign direct investment for many years. As a result, the technological progress and production capacity of China's manufacturing industry have been promoted rapidly, the substitutability of home produced capital goods (included those produced by foreign investment enterprises) to imported goods has been strength- 
ened, and therefore, the effect of RMB exchange rate on domestic investment spending is not clear. Fourth, one condition that devaluation can lead to a reduction in national output is that imports initially exceed exports (Krugman and Taylor 1978). China's trade balance has been in the favorable surplus for more than ten years except for 1993, and therefore does not satisfy that condition.

Finally, because of the characteristics of processing trade in China's manufacturing industry and administrative controls on prices (especially on those of service sector), the supply side effect of the RMB exchange rate on output is also uncertain. In a word, it seems that the expenditurechanging effect and supply side effect of the RMB exchange rate change are not remarkable in practice until now. Therefore, the effect of RMB exchange rate shock on China's output is mainly embodied through the expenditure-switching effect, as traditional macroeconomic theory emphasized. In that situation, the appreciations of RMB are likely contractionary.

It is worth pointing out, however, that the conclusion that appreciations have been contractionary in China does not necessarily mean that China should continue maintaining the undervalued RMB exchange rate, since the undervalued RMB has already caused the Chinese economy to run into internal and external imbalances in the past several years. Figure 3.2 tells us that China's real GDP has been running above its long-term trend since 2003, and this kind of deviation is expanding. Indeed, the overheating of the Chinese economy is obvious. There is no doubt that continuing the undervaluation of RMB exchange rate will further aggravate the imbalances of the Chinese economy. In fact, the conclusion that appreciations have been contractionary in China implies that relative to other effects of exchange rate change, the expenditure-switching effect has been predominant in China until now. Therefore, it is effectual to use the orthodox Swan Diagram to analyze macroeconomic policy issues in China. ${ }^{13}$ According to the Swan Diagram of Shi (2006), allowing RMB to appreciate is helpful for the Chinese economy to realize internal and external balances.

In addition, China's capital account surplus has increased rapidly along with the rapid increases in the current account surplus in recent years. The rapid increase in the "double surplus" causes China's foreign exchange reserve to expand in a wild manner and causes the money supply and the domestic credit to expand passively, which have aggravated the overheating of the Chinese economy and the difficulty in the government's attempt at macromanagement. In particular, as China's capital account liberalizes gradually and the effectiveness of capital controls erodes over time, the hot money will flow into China in great amounts, becoming one of the impor-

13. If appreciations (depreciations) are expansionary (contractionary), the Swan Diagram is less insightful about the combination of policy instruments to simultaneously fulfill both internal and external balances, because it it difficult in this case to decide where and how the internal and external balance schedules intercross. See, for example, Frankel (2005). 
tant reasons the foreign exchange reserve increase so fast. Our empirical work indicates that the effect of shocks on China's output through international finance channel (as represented by U.S. interest rate shocks) exceed that through international trade channels (as represented by RMB real exchange rate shocks), suggesting it is important for the Chinese authorities to handle the capital inflows problem correctly. The inflow of hot money in recent years is mainly a response to the expectations of RMB appreciation, and one of the important reasons for the persisting existence of the expectations is the undervaluation of RMB. Therefore, allowing RMB to appreciate at faster speed, so as to restore the equilibrium level of RMB exchange rate, will lessen the expectations of RMB appreciation, thus relaxing the pressure of the rapid increase in foreign exchange reserve on the Chinese authorities.

\section{References}

Akinlo, A. E., and Odusola, A. F. 2003. Assessing the impact of Nigeria's naira depreciation on output and inflation. Applied Economics 36:691-703.

Berument, H., and M. Pasaogullari. 2003. Effects of the real exchange rate on output and inflation: Evidence from Turkey. The Developing Economies, XLI4:401-35.

Branson, W. H. 1986. Stabilization, stagflation, and investment incentives: The case of Kenya, 1979-1980. In Economic adjustment and exchange rates in developing countries, eds. S. Edwards and L. Ahamed, 267-93. Chicago: University of Chicago Press.

Bruno, M. 1979. Stabilization and stagflation in a semi-industrialized economy. In International economic policy: Theory and evidence, eds. R. Dornbusch and J. A. Frenkel, 270-89. Baltimore, MD: Johns Hopkins University Press.

Caves, R. E., J. A. Frankel, and R. W. Jones. 2002. World trade and payments: An introduction. Reading, MA: Addison-Wesley.

Cochrane, J. H. 2005. Time Series for Macroeconomics and Finance. University of Chicago. Unpublished Manuscript.

Cooper, R. N. 1971. Currency devaluation in developing countries. In Government and economic development, ed. G. Ranis. New Haven, CT: Yale University Press.

Coudert, V., and C. Couharde. 2005. Real equilibrium exchange rate in China. CEPII Working Paper no. 2005-01. Paris: Center for International Prospective Studies.

Diaz-Alejandro, C.F. 1963. A note on the impact of devaluation and the redistributive effects. Journal of Political Economy 71:577-80.

Edwards, S. 1986. Are devaluations contractionary? The Review of Economics and Statistics 68:501-508.

Engle, R. R., and C. W. J. Granger. 1987. Co-integration and error correction representation, estimation, and testing. Econometrica 55:251-76.

Goldstein, M. 2004. Adjusting China's exchange rate policies. Revised version of the paper presented at the International Monetary Fund's seminar on China's Foreign Exchange System. May 26-27. Dalian, China. 
Gylfason, T., and M. Radetzki. 1991. Does devaluation make sense in the least developed countries? Economic Development and Cultural Change 40 (1): 1-25.

Frankel, J. A. 2004. On the Yuan: The choice between adjustment under a fixed exchange rate and adjustment under a flexible rate. Paper presented at an International Monetary Fund seminar on China's foreign exchange system. May 26-27. Dalian, China.

Frankel, J. A. 2005. Mundell-Fleming lecture: Contractionary currency crashes in developing countries. IMF Staff Papers, vol. 52, No. 2, pp. 149-92.

Hirschman, A. O. 1949. Devaluation and the trade balance: A note. The Review of Economics and Statistics 31:50-53.

Hoffmaister, A. W., and C. Vegh. 1996. Disinflation and the recession-now-versusrecession-later hypothesis: Evidence from Uruguay. IMF Staff Papers 43:355-94.

Johansen, S. 1995. Likelihood-Based Inference in Cointegrated Vector Autoregressive Models. Oxford, England: Oxford University Press.

Kamin, S. B., and J. H. Rogers. 2000. Output and the real exchange rate in developing countries: An application to Mexico. Journal of Development Economics 61 (1): 85-109.

Krugman, P., and L. Taylor. 1978. Contractionary effects of devaluation. Journal of International Economics 8:445-56.

Lizondo, S., and Montiel, P. J. 1989. Contractionary devaluation in developing countries: An analytical overview. IMF Staff Papers 36:182-227.

Moreno, R. 1999. Depreciations and recessions in East Asia. Federal Reserve Bank of San Francisco Economic Review, 3, 27-40.

Obstfeld, M., and K. Rogoff. 1995. Exchange rate dynamics redux. The Journal of Political Economy 103 (3): 624-60.

Shi, J. 2006. Adjustment of global imbalances and its impact on China's economy. China and World Economy 14 (3): 71-85.

Shi, J., and H. Yu. 2005. Renminbi equilibrium exchange rate and China's exchange rate misalignment: 1991-2004. Economic Research Journal (Jingji Yanjiu), 40 (4): 34-45.

Sims, C. 1980. Macroeconomics and reality. Econometrica 48:1-48.

Sims, C., J. Stock, and M. Watson. 1990. Inference in linear time series models with some unit roots. Econometrica 58 (1): 113-44.

Van Wijnbergen, S. V. 1986. Exchange rate management and stabilization policies in developing countries. Journal of Development Economics 23:227-47.

\section{Comment Ashvin Ahuja}

Shi's main contribution is in his measurement of the extent to which the RMB-USD exchange rate movement can affect important macroeconomic aggregates in China. In this regard, his handling of the data is careful and the result useful to Chinese policymakers.

The results he obtains also gives observers an idea why China's policy-

Alvin Ahuja is a senior economist at the Bank of Thailand.

Comment read at the 17th East Asian Seminar on Economics on "International Financial Issues Around the Pacific Rim," held on June 22-24, 2006 at Kona, Hawaii. 
makers are so reluctant to let the RMB float more in the short run. Shi's approach is as solid as can be expected from the classical econometric method of enquiry, given the time series limitation. Since the chapter has a nice summary of the history of the exchange rate regimes of China and of the main results, I will focus on policy implication and the robustness of the results with suggestion for further research.

How much should China revalue or let the RMB appreciate is the central issue in Asia and the world today. China and its currency are part and parcel of the global imbalances issue, and the relevance to Asian central banks is beyond question. When a relatively large trading nation such as China pegs, other central banks are forced to intervene in the foreign exchange market quite extensively as well, regardless of their appetite for such activity. This is evident in the pace at which Asian central banks accumulated international reserves, starting from 2002.

The chapter does not offer an extensive policy prescription for the Chinese policymakers on what they should do with the RMB exchange rate going forward. Having the economy grow briskly with price stability has helped lift millions out of poverty and raise the welfare of most ordinary Chinese citizens. Essentially, there is a strong case for China to be cautious about letting the nominal peg go. It needs to carry the public with it on the road of market reform. An economic slowdown that lasts longer than necessary can put those reforms at risk. Shi makes this important point. On a more palpable level, as a dollar peg is one way to anchor inflation expectations in China, a legitimate question is: what is the implication of leaving the peg or revaluation on inflation? Would it imply deflation? From Shi's conclusion, price stability would not be compromised.

There are policy implications for Asian regional economies as well. In Asia, one concern is the slowdown in the People's Republic of China (PRC) if the revaluation takes place, but there is also another in the excessive accumulation of U.S. dollars (USD), which can make regional economies more vulnerable when large USD correction comes. Also, Chinese and other Asian central banks' dollar reserves buildup has become increasingly harder to sterilize fully: the sterilization costs have mounted alongside shrinking central bank profits when measured in dollar terms; a politically important issue in some countries.

At issue may be not only whether RMB revaluation is contractionary to China, but also how much of an impact it makes on the regional economies in the short run. The answer may depend on the timing: if it takes place soon, when confidence is strong, capital is still flowing in, short-term foreign debt is small and reserves are large, the fallout could be more limited, for example. So, the timing matters a great deal. Taking these standard variables into account, the model used seems unable to give insight to the appropriate timing issue. 
The approach Shi takes is quite standard and expected from the first serious attempt to answer his well-posed question. But as a reader, I am left with doubt when it comes to a methodology that does not recognize the importance of the difference between structural relationships between economic variables and reduced-form variables. I am also uncomfortable with a model that suggests that currency appreciation is usually contractionary or associates depreciation with expansionary phases, regardless of the underlying shocks or economic and financial structure. We have plenty of examples whereby such associations only exist under specific contexts, as acknowledged in the paper itself.

I would also like to see subsequent work asking the same question, but using an alternative approach, by now standard, which is founded on microeconomic behavior of economic agents and uses the language of general equilibrium. It would allow us to probe the question in a deeper way and be more certain that the Chinese do not make systematic errors in reacting to (or anticipating) different policies over time. We could study the underlying forces or disturbances that may affect the Chinese GDP and the RMB in different ways from both the supply and demand sides. These underlying shocks may also be faced with other regional economies within the same timeframe. The policy implications may be drastically different from Shi's under this new approach, as different shocks are modeled and their effects on macroaggregates are studied.

The alternative approach can also afford us an opportunity to explore different policy alternatives under different setups. For instance, under a tightly managed floating system used in China, what is the implication on economic resiliency (how costly it is to the economy before it gets to a new equilibrium) when domestic prices and nominal wages are flexible or not so flexible? Theory predicts that a recession should be quick and less painful when prices are flexible. In the context of this unknown (not measured or documented in the paper, at least) flexibility of nominal wage-price contracts in China, how efficient or how long will it take Chinese farms and firms to adjust to an exchange rate shock? This, to me, seems central to the analysis and a policymaker's decision.

I'd also expect to see different policy responses if the government targets some sector's prosperity in particular. For instance, commodity (e.g., farm product) prices may be set differently in China from manufacturing tradables, for example. Shi's approach has its limit. However, policymakers' decision to allow appreciation at a faster pace may depend on pleasing different constituencies at different times. Moreover, we need to have the analysis under different policy alternatives in the United States, European Union, or Japan, which affect what China may do in response.

Overall, I think the chapter is solid, and it accomplishes what it sets out to do. Policymakers should take heed that Shi's model implies costly eco- 
nomic adjustment from RMB appreciation only for a short period of time. With domestic wage-price flexibility, adjustment may also be less painful than Shi's model implies.

\section{Comment Dante B. Canlas}

The chapter of Mr. Jianhuai Shi empirically assesses the output effects of currency revaluation in China using vector autoregression (VAR). To be forthright, Mr. Shi's answer to his question, which is the title of his chapter, is a "Yes."

The chapter departs from two observed imbalances in China's economy. One is external, the other, internal. China is posting a huge trade surplus in relation to the United States and other major trading partners. At the same time, China is experiencing some serious inflation pressure. In view of these twin imbalances, the exchange value of the renminbi (RMB) has been placed squarely in the policy hot seat.

The United States, in particular, is pressuring China to revalue the renminbi in an effort to scale up China's imports. At this stage, however, China's policymakers in charge of monetary policy are hesitating to do so for fear of inducing an output contraction. Instead, China is offering to tax its exports, ease capital controls, and adjust interest rates.

In aid of resolving the policy debate, Shi opens up a VAR-based investigation of the output effects of the RMB's revaluation using time series data for the period 1991Q1-2005Q3. Mr. Shi conducts the requisite tests - unit root and co-integration - and proceeds to estimate impulse-response functions. One of the results worth highlighting is the GDP decline from a contemporaneous shock to RMB's real exchange value. This result, according to Shi's results, wanes after 12 quarters. Granger causality tests confirm that the effects run from the RMB shock to GDP.

One question that arises as a matter of course from the VAR results is this: How much of the knowledge generated from the VAR tests translates into knowledge about the proper conduct of exchange-rate based stabilization? In other words, do VAR tests have the power to discriminate among alternative exchange-rate adjustment rules that would allow people in charge of monetary policy to determine the most effective rule for stabilization?

This is doubtful even if after doing a decomposition-of-variance analysis, the researcher is able to rank-order the contribution of various shocks to the variance of a particular variable, say, GDP. If VAR tests have the power to discriminate, then Mr. Shi should have been more definite about his policy recommendations. For example, would he have concluded the

Dante B. Canlas is a professor of economics at the University of the Philippines. 
following: "First of all, the conclusion that revaluations are contractionary in China does not mean that China would continue maintaining RMB exchange rate undervalued"? But who is the policymaker in China who is sufficiently brave to engineer a revaluation after being appraised by the best technical minds that such an action would be contractionary?

What I'm trying to do here is counsel caution in extracting policy recommendation from the results of the VAR tests. If one is bent on deriving appropriate exchange-rate adjustment measures in China, additional analytical work is indicated on other real factors that are causing the twin imbalances. Labor-market factors, for instance, deserve to be looked into. It is clear that political debates are being fueled by claims of a massive export of jobs to China, an issue that ultimately finds its way into the RMB exchange-rate debate. Neglect of aggregate labor-market variables like the real and money wage results in specification errors that ought to be rectified theoretically and empirically. 